\title{
Kultivasi Chlorella, sp Pada Media Tumbuh Yang Diperkaya Dengan Pupuk Anorganik Dan Soil Extract
}

\author{
${ }^{1}$ Sri Yadial Chalid, ${ }^{2}$ Sri Amini, ${ }^{1}$ Suci Dwi Lestari \\ ${ }^{1)}$ Program Studi Kimia, Fakultas Sains dan Teknologi UIN Syarif Hidayatullah Jakarta. \\ ${ }^{2)}$ Balai Besar Riset Pengolahan Produk dan Bioteknologi Kelautan dan Perikanan (BBRPPBKP) \\ K. S. Tubun Pertamburan VI Jakarta 10260. \\ Telp/Fax : (021) 53650157-53650158/53650158 \\ email : sriyadial@yahoo.com
}

\begin{abstract}
Abstrak
Mikro alga jenis Chlorophyceae SP adalah alga laut yang menghasilkan zat gizi seperti asam lemak tak jenuh omega-3, 6, dan 9, serat, vitamin, protein dan mineral. Warna hijau dari klorofil pada Chlorella,sp disebut darah hijau (green blood) mempunyai kandungan zat besi pembentuk hemoglobin. Pada Chlorella,sp kering terdapat enzim Superoxide dismutase (SOD) sekitar 10.00037.500 units per 10 gram yang merupakan anti radikal bebas untuk mencegah penuaan dini. Sementara produksi Chorophyceae secara alami masih terbatas, Untuk itu ada teknik budidaya alga dengan memanipulasi media hidup yaitu media sintetik. Penelitian ini adalah penelitian pendahuluan melihat pengaruh perlakuan media tumbuh terhadap pertumbuhan atau kepadatan sel dengan menggunakan Hemaesitometry. Pupuk anorganik proanalis dan soil extract ditambahkan ke dalam wadah kultivasi. Chlorella, sp pada umur kultivasi 13 hari menghasilkan jumlah sel tertinggi sebanyak 7,7567 log $\mathrm{sel} / \mathrm{mL}\left(5,7120 \times 10^{7} \mathrm{sel} / \mathrm{mL}\right.$. Chlorella, sp pada pupuk soil extract pada umur kultivasi 9 hari menghasilkan jumlah sel tertinggi sebanyak $5,7533 \log \mathrm{sel} / \mathrm{mL}\left(5,6666 \times 10^{7} \mathrm{sel} / \mathrm{mL}\right)$. Laju pertumbuhan Chlorella,sp menunjukkan hasil paling baik pada media kultivasi yang menggunakan pupuk anorganik (conwy) dibandingkan dengan pupuk soil extract.
\end{abstract}

Kata Kunci : Chlorella, sp, SOD, pupuk anorganik, soil extrac.

\begin{abstract}
Chlorella, $s p$ is a kind of algae. Naturally Chlorella, $s p$ life in the sea a limited amount. They have produced the nutritions : omega-3,6 and 9 acid fat,vitamine, protein, mineral and chlorofil. It also contain an Antioxidant enzyme such as Superoxide dismutase (SOD). This enzyme have an ability as radicals scavenging. The enzyme activity of SOD is 10.000-37.500 units $/ 10 \mathrm{~g}$ of wet weight. The present primery research by doing modification of media as habitate of Chlorella, sp.,. Anorganic and soil extract fertilizer were added to $10^{4}$ cell $/ \mathrm{ml}$ Chlorella, $s p$. and then the density of Chlorella, $s p$ was measured by Haemacytometer. It was found that the highest cell of Chlorella, sp showed after 13 days cultivification was $7,7567 \log$ cells $/ \mathrm{mL}\left(5,7120 \times 10^{7}\right.$ cells $1 / \mathrm{mL}$ on anorganic media. Chlorella, $s p$ on soil extract were found the highest cells was $5,7533 \log$ cels $1 / \mathrm{mL}\left(5,6666 \times 10^{7}\right.$ cells $\left./ \mathrm{mL}\right)$ after 9 days cultivication $\mathrm{r}$. The growth of Chlorella,sp was found to be the best on media cultivivication using anorganic (conwy) fertilizer.
\end{abstract}

Key Word : Chlorella, sp, SOD, Anorganic fertilizer, soil extract

\section{PENDAHULUAN}

Mikroalga atau ganggang adalah organisme perairan yang lebih dikenal dengan fitoplankton (alga laut bersel tunggal). Organisme ini dapat melakukan fotosintesis dan hidup dari nutrien anorganik serta menghasilkan zat-zat organik dari $\mathrm{CO}_{2}$ oleh fotosintesis. Mikroalga mempunyai zat warna hijau daun (pigmen) klorofil yang berperan pada proses fotosintesis dengan bantuan $\mathrm{H}_{2} \mathrm{O}, \mathrm{CO}_{2}$ dan sinar matahari untuk menghasilkan energi. Energi ini digunakan untuk biosintesis sel, pertumbuhan dan pertambahan sel, bergerak atau berpindah dan 
reproduksi (Pranayogi, D. 2003). Disamping itu famili ganggang halus Chlorophyceae menghasilkan asam lemak tak jenuh omega-3, 6, dan 9, serat, vitamin, protein, dan mineral. Kandungan beta karoten 900 lebih banyak dibandingkan dengan wortel. Sedangkan kandungan omega-3 mikroalga lebih banyak dibandingkan minyak ikan, biji rami, dan kedelai, yaitu 50-60 persen (Sukoso, 2002).

Chlorella, $s p$ tumbuh pada media yang mengandung cukup unsur hara, seperti nitrogen, fosfor, kalium. Chlorella, $s p$ akan tumbuh baik pada temperatur optimal $25^{\circ}$ C. Nutrisi yang diperlukan alga dalam jumlah besar adalah karbon, nitrogen, fosfor, sulfur, natrium, magnesium, kalsium. Sedangkan unsur hara yang dibutuhkan dalam jumlah relatif sedikit adalah besi, tembaga $(\mathrm{Cu})$, mangan $(\mathrm{Mn})$, seng $(\mathrm{Zn})$, silikon $(\mathrm{Si})$, boron (B), molibdenum (Mo), vanadium (V) dan kobalt (Co) (Chumadi, dkk. 1992).

Mengingat begitu kayanya zat gizi yang terkandung pada Chlorella,sp dan aplikasinya yang sangat luas pada industri pangan maupun kosmetik. Maka perlu dilakukan upaya budidaya Chlorella,sp dengan cara memanipulasi media hidup, menggunakan pupuk anorganik dan soil extract. Penelitian ini bertujuan mencari media buatan yang terbaik untuk pertumbuhan Chlorella,sp., menentukan pengaruh penambahan pupuk anorganik dan pupuk soil extract terhadap kepadatan sel ganggang halus laut jenis Chlorella,sp. Menurut Amini 2005 memerlukan unsur hara untuk pertumbuhan dan perkembangbiakannya.

Di negara Jepang, Amerika, Eropa, Australia dengan perkembangan bioteknologi telah meluncurkan produk pangann yang dikenal dengan makanan kesehatan. Di Indonesia suplemen yang bahan dasarnya diperoleh dari mikroalga diberi nama dengan Hi-Liena dari jenis spirulina, sp., Dunaliella, dari Dunaliella,sp., Clostanin dari jenis Chlorella,sp. Produk non pangan dari seperti body lotion, sampo dengan merk Miho body lotion dan Miho body sampo dengan bahan dasar Chlorella,sp.(Kabinawa, 2001). Selain itu, Chlorella, sp juga memiliki daya biosorbsi yang kuat terhadap logam berat, sehingga dapat dimanfaatkan untuk menetralisir limbah industri. Pada negara maju Chorella, sp disamping didapatkan melalui proses bioteknologi, mereka juga mengembangkan metode budidaya dengan teknik kultur (Dainith and Meley, 1993)

Tabel 1. Komposisi Nutrisi Mikroalga

\begin{tabular}{l|l}
\hline \multicolumn{1}{c|}{ Komposisi Kimia } & \multicolumn{1}{|c}{ Jumlah (\%) } \\
\hline Protein & $30-55$ \\
Karbohidrat & $10-30$ \\
Lemak & $10-25$ \\
Mineral & $10-40$ \\
Asam Nukleat & $4-6$ \\
\hline
\end{tabular}

Sumber : Pranayogi, D. (2003)

1. Pupuk Anorganik Pro Analis (Media Conwy) Terdiri dari:

Larutan A

Larutan ini mengandung berbagai macam zat kimia, yaitu $\mathrm{FeCl}_{3} \cdot 6 \mathrm{H}_{2} \mathrm{O}, \mathrm{MnCl}_{2} \cdot 4 \mathrm{H}_{2} \mathrm{O}$, $\mathrm{H}_{3} \mathrm{BO}_{4}, \mathrm{Na}$-EDTA, $\mathrm{NaH}_{2} \mathrm{PO}_{4} \cdot 2 \mathrm{H}_{2} \mathrm{O}, \mathrm{NaNO}_{3}$ yang dilarutkan dalam aquadest.

Larutan B

Larutan ini terdiri dari $\mathrm{ZnCl}_{2}, \mathrm{CoCl}_{2} \cdot 6 \mathrm{H}_{2} \mathrm{O}$, $\left(\mathrm{NH}_{4}\right) \mathrm{MO}_{7} \mathrm{O}_{24} .4 \mathrm{H}_{2} \mathrm{O}, \mathrm{CuSO}_{4} .5 \mathrm{H}_{2} \mathrm{O}$ yang dilarutkan dalam aquadest.

2. Soil Extract (Pupuk Organik)

Tanah yang diambil merupakan tanah yang mengandung unsur-unsur penting bagi pertumbuhan mikroalgae Unsur-unsur tersebut diantaranya adalah Nitrogen $(\mathrm{N})$, Fosfor (P), Kalium (K), Kalsium (Ca), Magnesium (Mg), Belerang (S).

Unsur hara berperan untuk memperbaiki pertumbuhan vegetatif tanaman, membantu pembelahan sel, pembentukan albumin, pembentukan bunga, buah dan biji, mempercepat pematangan, memperkuat batang, perkembangan akar, memperbaiki kualitas tanaman terutama sayur-mayur dan makanan ternak, tahan terhadap penyakit, membentuk nucleoprotein Disamping itu unsur hara adalah unsur penyusun jaringan tanaman, pembentukan pati, mengaktifkan enzim, pembentukan stomata (mengatur pernapasan dan penguapan), proses fisiologis dalam tanaman, proses metanolik dalam sel, mempengaruhi penyerapan unsur-unsur lain, mempertinggi daya tahan terhadap kekeringan dan penyakit, dan membantu perkembangan 
akar, penyusunan dinding sel tanaman dan pembelahan sel, untuk tumbuh (elongation). Unsur-unsur Mikro dalam tanah berasal dari mineral-mineral dalam bahan induk tanah dan bahan organik (Cotton, 1989). Agar tanaman dapat tumbuh baik perlu adanya keseimbangan jumlah unsur hara dalam tanah sesuai dengan kebutuhan tanaman akan unsur hara tersebut.

Chlorella,sp mempunyai pigmen warna hijau dan kaya dengan warna biru yang disebut Phycocyanin merupakan protein complek. Phycocyanin merupakan pembentuk darah putih didalam tubuh manusia dan merupakan antibodi atau pembentuk imunitas dari serangan racun kimia dan radiasi. Warna hijau dari klorofil pada Chlorella,sp disebut darah hijau (green blood) mempunyai kandungan zat besi pembentuk hemoglobin yang berfungsi sebagai penambah makanan bagi penyandang anemia. Pada Chlorella,sp terdapat warna kuning oranye mrupakan kandungan karoten terdiri dari xanthopill, myxoxanthopill, zeaxathin, cryptoxanthin, echinenone, fucoxanthin, violaxanthin dan astaxanthin. Total karoten yang terdapat pada Chlorella,sp per 10 gr yaitu $0,37 \%$ (Pranayogi, 2003). Karoten mempunyai khasiat pada manusia sebagai antioksidan. Chlorella,sp mengandung polisakarida sebanyak 15 - 25 gr merupakan karbohidrat yang mudah diserap didalam darah. Pada Chlorella,sp kering terdapat enzim Superoxide dismutase (SOD) sekitar 10.000-37.500 units per 10 gram yang merupakan anti radikal bebas untuk mencegah penuaan dini.

\section{METODE PENELITIAN}

\section{Alat dan Bahan}

Peralatan yang digunakan adalah : aerator, autoklaf, Haemocytometer Neubauer, Hand counter, kuvet kaca, membran selulose filter paper (kertas saring) Whatman No. 5, mikroskop,Vortex Thermolyne Maxi Mix II Sybron, wadah kultivasi kapasitas 3 liter.

Bahan- bahan yang digunakan adalah ganggang halus laut jenis Chlorella,sp, pupuk conwy, pupuk soil extract, air laut, aquadest, alkohol, aseton.

\section{Pembuatan Pupuk Anorganik Proanalis Conwy}

Larutan A : Terdiri dari 100,0 $\mathrm{g} \mathrm{NaNO}_{3}, 20,0 \mathrm{~g}$ $\mathrm{NaHPO}_{4} \cdot 2 \mathrm{H}_{2} \mathrm{O}, 45,0 \mathrm{~g} \mathrm{Na}-\mathrm{EDTA}, 33,6 \mathrm{~g} \mathrm{H}_{3} \mathrm{BO}_{4}$, $0,78 \mathrm{FeCl}_{3} \cdot 6 \mathrm{H}_{2} \mathrm{O}, 0,36 \mathrm{~g} \mathrm{MnCl}_{2} \cdot 4 \mathrm{H}_{2} \mathrm{O}$ yang dilarutkan dalam $1000,0 \mathrm{~mL}$ aquadest.

Larutan $B$ : Terdiri dari d 2,1 $\mathrm{g} \mathrm{ZnCl}_{2}, 2,0 \mathrm{~g}$ $\mathrm{CoCl}_{2} \cdot 6 \mathrm{H}_{2} \mathrm{O}, 0,9$ g $\mathrm{CuSO}_{4} \cdot 5 \mathrm{H}_{2} \mathrm{O}$, dan $0,9 \mathrm{~g}$ $\left(\mathrm{NH}_{4}\right) \mathrm{Mo}_{7} \mathrm{O}_{24} \cdot 4 \mathrm{H}_{2} \mathrm{O}$, yang dilarutkan dalam $100,0 \mathrm{~mL}$ aquadest.

Masing-masing larutan dimasukkan ke dalam autoklaf untuk disterilisasi. Sebanyak 1 mL larutan A dan $1 \mathrm{~mL}$ larutan B ditambahkan ke dalam 1 Liter air laut.

\section{Pupuk Anorganik SE (soil extract)}

Tanah sebanyak $1 \mathrm{~kg}$ dimasukkan ke dalam becker glass $2000 \mathrm{~mL}$, kemudian direndam dengan $1 \mathrm{~L}$ air. Diamkan semalaman sampai mengendap, kemudian diambil lapisan bagian atas untuk digunakan sebagai pupuk.

\section{Penumbuhan Mikroalga}

Air laut sebanyak 2.5 liter dengan salinitas 25 ppt dimasukkan ke dalam enam buah wadah kaca transparan berukuran 3 liter. Tiga buah wadah ditambahkan $1 \mathrm{~mL}$ pupuk conwy, dan tiga buah wadah lagi ditambahkan $1 \mathrm{~mL}$ pupuk soil extract. Ke dalam semua wadah diinokulasikan ganggang halus jenis Chlorella,sp dengan kepadatan sel awal $10^{4}$ $\mathrm{sel} / \mathrm{mL}$. Semua wadah ditempatkan di dalam ruangan terkontrol dengan temperatur $25^{\circ} \mathrm{C}$ dan intensitas cahaya 2000 Lux serta diaerasi secara terus menerus. Ambil $1 \mathrm{~mL}$ sampel dari tiap wadah pada hari ke 1, 3, 5, 7, 9, 11, 13 untuk menghitung jumlah sel Chlorella,sp.

\section{Penghitungan Kepadatan Sel}

Kultur sel Chlorella,sp dalam tiap wadah diambil sebanyak $1 \mathrm{~mL}$ dan dimasukkan ke dalam tabung reaksi untuk dilakukan perhitungan kepadatan selnya. Kepadatan populasi sel yang dihasilkan dalam skala waktu dapat ditentukan dengan menggunakan alat haemocytometer. Cara penggunaan haemocytometer ini yaitu dengan cara 
meneteskan kultur sel Chlorella,sp yang akan dianalisa kepadatan selnya sebanyak satu tetes ke masing-masing dua bagian haemocytometer. Tutup dengan menggunakan slide. Haemocytometer ini dilengkapi dengan mikroskop. Haemocytometer yang telah diberikan kultur sel Chlorella,sp diletakkan di bawah lensa objektif dan difokuskan hingga terlihat kisi-kisi tempat perhitungan sel yang terdiri dari lima kisi perhitungan.

Kepadatan sel dapat dihitung dengan persamaan berikut :

$$
\left\langle\frac{n}{x}\right\rangle\left\langle\frac{10.000}{1}\right\rangle=\mathrm{Sel} / \mathrm{mL}
$$

Keterangan :

$\mathrm{n}=$ total sel hasil perhitungan

$\mathrm{x}=$ faktor divisi berdasarkan persentase dari masing-masing kisi perhitungan. yang digunakan pada penelitian ini yaitu $25 \%$ dengan faktor divisi $=1$

Sedangkan laju pertumbuhan dapat dihitung dengan persamaan:

$$
\mathrm{K}=\frac{\log 10 \frac{N}{N o}}{t-t o} \times 3,22
$$

Keterangan :

$\mathrm{N}=$ Kepadatan Sel pada waktu $\mathrm{t}$

No = Kepadatan Sel Awal

$\mathrm{t}_{\mathrm{o}} \quad=$ Waktu Awal

$\mathrm{t} \quad=$ Waktu

$3,22=$ Nilai Konstanta

\section{HASIL DAN PEMBAHASAN}

\section{Kepadatan Sel Chlorella,sp dengan Pupuk Anorganik}

Hasil penelitian ini menunjukkan bahwa terdapat interaksi antara umur kultivasi dengan jenis ganggang halus laut yang digunakan terhadap kepadatan sel. Pupuk anorganik proanalis (conwy) yang ditambahkan ke dalam wadah kultivasi. Chlorella, sp pada umur kultivasi 13 hari menghasilkan jumlah sel tertinggi sebanyak $7,7567 \quad \log \quad$ sel $/ \mathrm{mL}$ $\left(5,7120 \times 10^{7} \mathrm{sel} / \mathrm{mL}\right) \quad$ (Amini 2004) seperti dinyatakan pada Gambar 1.

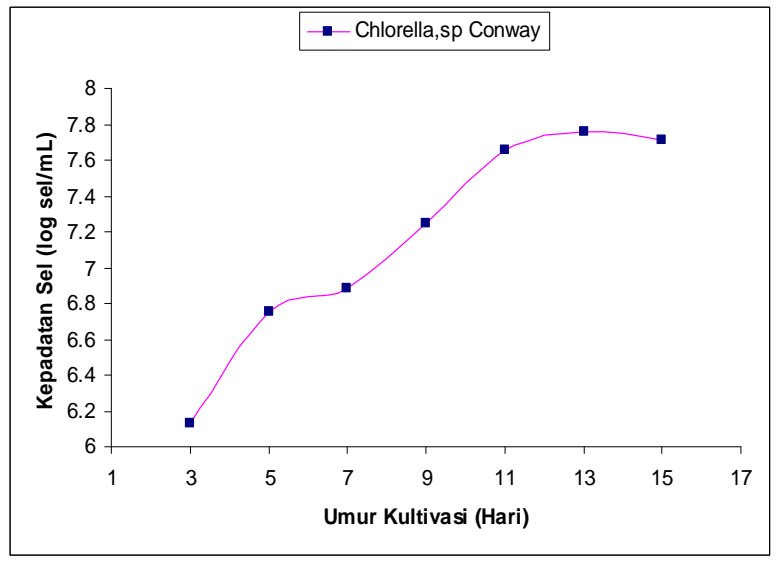

Gambar 1. Grafik Kepadatan Sel Chlorella, $s p$ (log $\mathrm{sel} / \mathrm{mL}$ ) dengan Pupuk Proanalis Anorganik (conwy).

Dari grafik yang dihasilkan pada Gambar 1 pada kultivasi ganggang Chlorella,sp. terlihat bahwa pertumbuhan ganggang halus laut dengan menggunakan pupuk anorganik proanalis (conwy) memiliki umur pertumbuhan paling lama. Ternyata pertumbuhan sel Chlorella, $s p$ berjalan lambat, sehingga pertumbuhan optimal atau fase eksponensial baru dicapai pada hari ke 13. Pada fase eksponensial yaitu pertumbuhan yang sangat cepat adalah pada fase dimana diproduksi pigmen yang terbanyak. Perkiraan jumlah pigmen dari mikroalga diukur dari kepadatan sel pada setiap volume kulturnya (log sel/mL). Jumlah kepadatan sel sebanding dengan meningkatnya jumlah kandungan pigmen yang dihasilkan (Amini 2004). Pada hari selanjutnya pertumbuhan Chlorella, sp mengalami fase stasioner dimana pertumbuhan sel minimal dan kepadatan sel mulai mengalami kemunduran terus-menerus hingga akhirnya memasuki fase kematian pada umur kultivasi 9-15 hari. Kepadatan sel juga dipengaruhi oleh temperatur, aerasi, cahaya, dan pH (Boyd, 2004) Temperatur yang digunakan pada penelitian ini adalah $25^{\circ} \mathrm{C}$, pada temperatur inilah mikroalga dapat tumbuh dengan baik. $\mathrm{pH}$ media pertumbuhan ganggang halus laut pada pupuk anorganik proanalis (conwy) adalah antara 7,5 - 8,5. Sedangkan nilai $\mathrm{pH}$ optimum untuk pertumbuhan ganggang halus laut berkisar antara 8,0 - 11,0 (Chumadi, dkk.1992), 
Tabel 2. Nilai pH Media Kultivasi Ganggang Halus Laut dengan Menggunakan Pupuk Anorganik (conwy)

\begin{tabular}{c|c}
\hline Jenis & $p H$ \\
\hline CCW $_{1}$ & $7-8$ \\
CCW $_{2}$ & $7-8$ \\
CCW $_{3}$ & $7-8$ \\
\hline
\end{tabular}

Keterangan : $\mathrm{CCW}_{1}, \mathrm{CCW}_{2}, \mathrm{CCW}_{3}$ : Chlorella,sp, pupuk anorganik proanalis (conwy)

Faktor pendukung lainnya adalah salinitas, yaitu tingkat kadar garam di dalam perairan. Besarnya salinitas berbeda-beda, tergantung evaporasi dan presipitasi. Organisme yang hidup dalam suatu perairan memiliki tingkat kepekaan yang berbeda-beda terhadap salinitas, tergantung spesies dan tingkat kehidupan. Kehidupan ganggang halus laut jenis Chlorella,sp cukup toleran pada lingkungan dengan kadar garam $0-70$ ppt. Tabel 5 . menunjukkan salinitas pada media kultivasi ganggang halus laut.

Tabel 3. Salinitas Media Kultivasi Ganggang Halus Laut Dengan Pupuk Anorganik (Conwy)

\begin{tabular}{c|c}
\hline Jenis & Salinitas \\
\hline $\mathrm{CCW}_{1}$ & $35 \mathrm{ppt}$ \\
$\mathrm{CCW}_{2}$ & $35 \mathrm{ppt}$ \\
$\mathrm{CCW}_{3}$ & $35 \mathrm{ppt}$ \\
\hline
\end{tabular}

Keterangan : $\mathrm{CCW}_{1}, \mathrm{CCW}_{2}, \mathrm{CCW}_{3}$ : Chlorella,sp, pupuk anorganik proanalis (conwy)

\section{Kepadatan Sel Chlorella,sp dengan Pupuk Soil extract}

Kandungan unsur hara di dalam tanah yang menyebabkan meningkatnya jumlah sel Chlorella,sp di antaranya nitrogen, belerang, fosfor, kalsium dan magnesium. Nitrogen dan belerang. Unsur-unsur ini berperan dalam pembentukan protein dan membentuk warna hijau pada Chlorella,sp. (Amini, 2004). Fosfor dan kalsium berperan dalam pembelahan sel, sehingga semakin cepat pembelahan sel terjadi semakin cepat pertumbuhan dan kepadatan sel. Magnesium berfungsi dalam pembentukkan minyak, sehingga mikroalga dapat menghasilkan minyak yang saat ini masih dikembangkan dalam upaya mencari bahan bakar pengganti bahan bakar fosil.

Hasil penelitian ini menunjukkan bahwa terdapat interaksi antara umur kultivasi dengan jenis ganggang halus laut yang digunakan terhadap kepadatan sel yang dihasilkan, serta berdasarkan pupuk organik yang dimasukkan ke dalam wadah kultivasi. Ganggang halus laut jenis Chlorella, $s p$ dengan menggunakan pupuk soil extract pada umur kultivasi 9 hari menghasilkan jumlah sel tertinggi sebanyak $5,7533 \log \mathrm{sel} / \mathrm{mL}\left(5,6666 \times 10^{7} \mathrm{sel} / \mathrm{mL}\right)$ seperti pada Gambar 2.

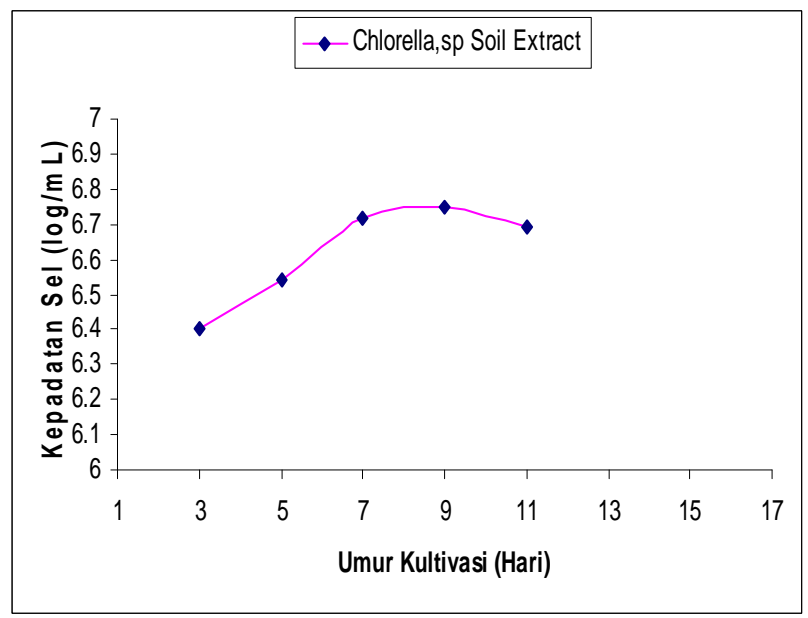

Gambar 2. Grafik Kepadatan Sel Chlorella, sp (log $\mathrm{sel} / \mathrm{mL}$ ) dengan Pupuk Soil Extract.

Dari Gambar 2., terlihat bahwa pertumbuhan ganggang halus laut dengan menggunakan pupuk soil extract memiliki umur pertumbuhan yang lebih pendek dibandingkan dengan menggunakan pupuk anorganik proanalis (conwy) dan tidak dapat bertahan hidup pada kultivasi ganggang halus laut jenis Chlorella,sp. Pada media kultivasi yang menggunakan pupuk soil extract pertumbuhan sel Chlorella, sp berjalan lebih cepat dibandingkan dengan menggunakan pupuk anorganik (conwy), sehingga mencapai pertumbuhan optimal atau fase eksponensial pada hari ke 9. Pada hari selanjutnya pertumbuhan Chlorella, $s p$ mengalami fase stasioner dan kepadatan sel mulai mengalami kemunduran terus-menerus hingga akhirnya memasuki fase kematian pada umur kultivasi 11 hari. Hal ini disebabkan 
adanya kehadiran kontaminan yang menggangu pertumbuhan sel Chlorella,sp.

Temperatur yang digunakan adalah $25^{\circ} \mathrm{C}$, karena pada temperatur inilah mikroalga dapat tumbuh dengan baik. Nilai $\mathrm{pH}$ yang dihasilkan oleh ganggang halus laut yang diberikan pupuk soil extract adalah $\mathrm{pH}$ antara 7,5 - 8,5. Sedangkan nilai $\mathrm{pH}$ tanah yang optimum untuk pertumbuhan ganggang halus laut berkisar antara 7,0-8,0 (Chumadi, dkk.1992), seperti yang terdapat pada penambahan pupuk soil extract yang ditunjukkan pada Tabel 4.

Tabel 4. Nilai $\mathrm{pH}$ Media Kultivasi Ganggang Halus Laut Dengan Menggunakan Soil Extract

\begin{tabular}{c|c}
\hline Jenis & $p H$ \\
\hline $\mathrm{CSE}_{1}$ & $7,5-8,5$ \\
$\mathrm{CSE}_{2}$ & $7,5-8,5$ \\
$\mathrm{CSE}_{3}$ & $7,5-8,5$ \\
\hline
\end{tabular}

Keterangan : $\mathrm{CSE}_{1}, \mathrm{CSE}_{2}, \mathrm{CSE}_{3}$ : Chlorella,sp, pupuk Soil Extract

Besarnya salinitas berbeda-beda, tergantung evaporasi dan presipitasi. Organisme yang hidup dalam suatu perairan memiliki tingkat kepekaan yang berbeda-beda terhadap salinitas, tergantung spesies dan tingkat kehidupan. Kehidupan ganggang halus laut jenis Chlorella,sp cukup toleran pada lingkungan dengan kadar garam $0-70$ ppt. Tabel 5 . menunjukkan salinitas pada media kultivasi ganggang halus laut.

Tabel 5. Salinitas Media Kultivasi Ganggang Halus Laut dengan Pupuk Soil Extract

\begin{tabular}{l|c}
\hline Jenis & Salinitas \\
\hline $\mathrm{CSE}_{1}$ & $30 \mathrm{ppt}$ \\
$\mathrm{CSE}_{2}$ & $30 \mathrm{ppt}$ \\
$\mathrm{CSE}_{3}$ & $30 \mathrm{ppt}$ \\
\hline
\end{tabular}

Keterangan : $\mathrm{CSE}_{1}, \mathrm{CSE}_{2}, \mathrm{CSE}_{3}$ : Chlorella,sp, pupuk Soil Extract.

\section{Laju Pertumbuhan Chlorella,sp}

Dari grafik yang dihasilkan pada Gambar 5 Grafik Laju pertumbuhan Chlorella,sp paling baik pada media kultivasi yang menggunakan pupuk anorganik (conwy) dibandingkan dengan pupuk soil extract. Pada media kultivasi yang menggunakan pupuk anorganik (conwy) laju pertumbuhan sel Chlorella,sp sangat cepat dan memiliki umur pertumbuhan paling lama dibandingkan dengan pupuk soil extract, hingga mencapai pertumbuhan optimal atau fase eksponensial pada hari ke 13. Sedangkan laju pertumbuhan chlorella,sp dengan media kultivasi pupuk soil extract, mengalami pertumbuhan optimal atau fase eksponensial pada hari ke 9. Pada hari selanjutnya pertumbuhan Chlorella, sp mengalami fase stasioner dan laju pertumbuhan sel Chlorella,sp mulai mengalami kemunduran terus-menerus hingga akhirnya memasuki fase kematian pada umur kultivasi 11 hari. Hal ini disebabkan adanya kehadiran kontaminan yang menggangu laju pertumbuhan sel Chlorella,sp.

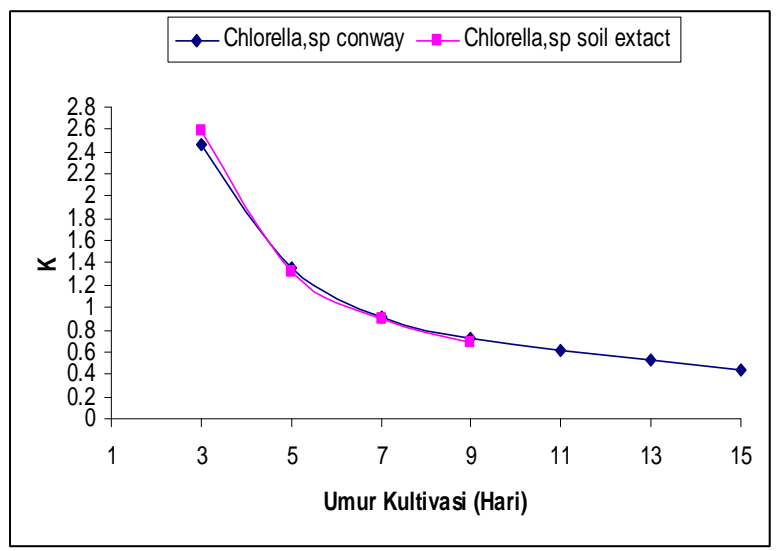

Gambar 3. Grafik Laju Pertumbuhan Chlorella,sp

Dari grafik laju pertumbuhan di atas dapat dijelaskan bahwa laju pertumbuhan optimal atau fase eksponensial pada Chlorella,sp baik yang menggunakan media kultivasi pupuk anorganik (conwy) maupun menggunakan pupuk soil extract terjadi pada hari ke 3. Sedangkan laju pertumbuhan Chlorella,sp mulai mengalami kemunduran atau mengalami fase kematian dengan menggunakan media kultivasi pupuk anorganik (conwy) terjadi pada hari ke 15. 


\section{KESIMPULAN DAN SARAN}

\section{Kesimpulan}

Kepadatan sel tertinggi ganggang halus laut pada media tumbuh yang diperkaya dengan pupuk anorganik proanalis (conwy) memiliki umur pertumbuhan paling lama dibandingkan pupuk soil extract pada kultivasi ganggang halus laut jenis Chlorella,sp.

\section{Saran}

Disaran untuk menentukan kadar pigmen atau zat warna yang dihasilkan oleh Chlorella,sp. pupuk anorganik proanalis (conwy) dan pupuk soil extract

\section{DAFTAR PUSTAKA}

1. Amini,S. 2004. Pengaruh Umur Ganggang Halus Laut jenis Chlorella,sp dan Dunaliella,sp terhadap Pigmen Klorofil dan Karotenoid Sebagai Bahan Baku Makanan Kesehatan. Jakarta: Seminar Nasional \& Temu Usaha, Fakultas Pertanian Universitas Sahid.

2. Amini,S. 2005. Konsentrasi Unsur Hara pada Media dan Pertumbuhan Chlorella Vulgaris dengan Pupuk Organik Teknis dan Analis. Jurnal Perikanan (J.Fish Sci) VIII (2):201-206. UGM, Jurusan Perikanan Fakultas Petanian

3. Boyd, J. 2004. Oceanography, Water, Seawater Ocean Circulation and Dinamics. Chemical week, June 29. Pub Ink USA.

4. Chumadi, dkk. 1992. Pedoman Teknis Budidaya Pakan Alami Ikan dan Udang. Jakarta: Pusat Penelitian dan Pengembangan Perikanan.

5. Cotton, F.A, Wilkinson,G. 1989. Kimia Anorganik Dasar. Jakarta: UI-Press.

6. Dainith, M. and C. O'Meley. 1993. Algae Cultures for Marine Hatcheries. Turtle Press. Australia. P. 1-9.

7. Kabinawa, I.N.K. 2001. Mikroalga sebagai Sumber Daya Hayati (SDH) Perairan dalam Perspektif Bioteknologi. Bogor: Puslitbang Bioteknologi Lembaga Ilmu Pengetahuan Indonesia.

8. Pranayogi, D. 2003. Studi Potensi Pigmen Klorofil dan Karotenoid dari Mikroalga Jenis Chlophyceae. Lampung: Universitas Lampung.
9. Sukoso. 2002. Peranan Bioteknologi Molekuler dalam Pembangunan Bidang

10. Perikanan dan Kelautan Indonesia. Malang: Universitas Brawijaya. 